
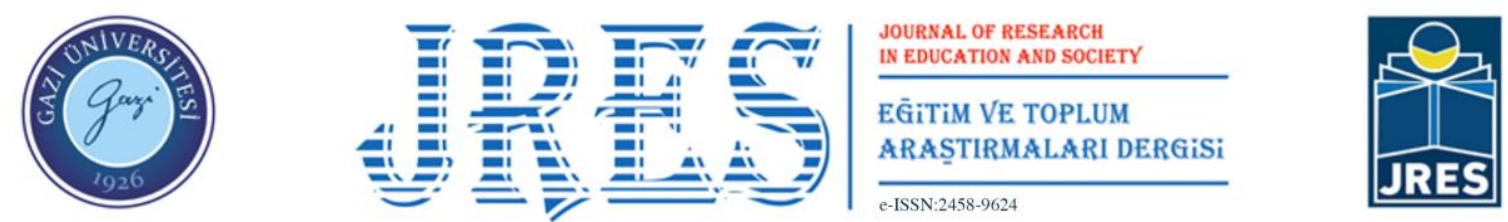

Cilt: 8 Sayı: 2 Sayfa Aralığı: 258-279 e-ISSN: 2458-9624 DOI: 10.51725/etad.923021

\title{
The Examination of Relationships among Personal-Familial \\ Qualifications, Levels of Parentification, Depression and Marital Satisfaction of Married Individuals*
}

\author{
Evli Bireylerin Kişisel-Ailesel Özellikleri, Ebeveynleştirilme, Depresyon ve \\ Evlilik Doyum Düzeyleri Arasındaki İlişkinin İncelenmesi
}

\section{Tolga Zencir}

\begin{abstract}
This study aims to investigate the relationship among levels of parentification, depression and marital satisfaction of married individuals; to examine how married individuals' personal-familial characteristics affect the level of parentification. 597 married people (244 men, 353 women) filled in "Parentified Child Scale-Adult Version", "Beck Depression Scale", "Marital Satisfaction Scale", and "Personal Information Form". Parentification and depression levels of married individuals statistically predict marital satisfaction. Parentification levels statistically significantly predict individuals' depression levels. While the main effect is observed in the parentification levels according to the familial and personal variables (permanent illness in the family, spending time with the parents, substance abuse in the family, the father's employment status, one of the parents working outside the province; the number of siblings and condition of working in childhood), the other variables indicate that there is no significant difference on their parentification level.
\end{abstract}

ÖZ
Bu araştırmanın amacı evli bireylerin ebeveynleştirilme, depresyon ve evlilik doyumu
düzeyleri arasındaki ilişkiyi incelemek; kişisel ve ailesel özelliklerinin de ebeveynleştirilme
düzeylerine temel etkisini ortaya koymaktır. Çalışmanın araştırma grubu olan 597 evli bireye
(244 erkek, 353 kadın) “Ebeveynleştirilmiş Çocuk Ölçeği- Yetişkin Formu”, "Beck Depresyon
Ölçeği”, "Evlilik Doyum Ölçeği”, demografik özellikleri elde etmek için hazırlanmış olan
"Kişisel Bilgi Formu” verilmiştir. Araştırma sonucuna göre, evli bireylerin ebeveynleştirilme
ve depresyon düzeyleri evlilik doyumlarını istatistiksel olarak yordamaktadır. Ayrıca,
ebeveynleştirilme düzeyleri, bireylerin depresyon düzeylerini de istatisiksel olarak anlamlı
bir şekilde yordamaktadır. Evli bireylerin ailesel ve kişisel niteliklerine göre de bazı
değişkenler (ailede kalıcı rahatsılık olma durumu, ebeveynler ile zaman geçirme, aile
madde bağımlılığı durumu, babanın çalışma durumu, ebeveynlerden birinin il dışında
çalışma durumu; kardeş sayısı ve çocukken çalışma durumu) açısından ebeveynleştirilme
düzeylerinde anlamlı bir temel etki görülürken, diğer değişkenler açısından ise anlamlı bir
fark tespit edilmemiştir.

Makale Bilgileri
Anahtar Kelimeler
Ebeveynleşme
Ebeveynleştirilmiş çocuk
Evlilik doyumu
Depresyon
Keywords
Parentification
Parentified child
Marital satisfaction
Depression
Makale Geçmişi
Geliş: $20 / 04 / 2021$
Düzeltme: $29 / 06 / 2021$
Kabul: $05 / 10 / 2021$

qualifications, levels of
8(2), $\quad 258-279$.
Atıf için: Zencir, T. (2021). The examination of relationships among personal-familial qualifications, levels of parentification, depression and marital satisfaction of married individuals. JRES, 8(2), 258-279. https://doi.org/10.51725/etad.923021

Etik Bildirim: This study was carried out in accordance with the approval of Hacettepe University Ethics Committee dated July 17, 2018 and numbered 35853172-300.

\footnotetext{
* This study was produced from the author's master's thesis.
} 


\section{Introduction}

It is an undeniable fact that the family of origin influences the individuals' development (CihanGüngör, 2007). Theories explaining human behaviors and development process have affected interpersonal relationships, social learning, modeling, identification, and reward-punishment, and so on (Bronfenbrenner, 1979). Therefore, the importance of the family of origin emerges, and it is seen that it can affect an individual's behavior patterns in the future. If family members' roles and responsibilities become clear, all family members might get their roles and responsibilities easily. In addition, the boundaries can be certain. Minuchin, Rosman, and Baker (1978) stated that parents should not have forgotten their responsibilities by staying within their own borders, and they should have kept their children away from these roles and responsibilities. Accordingly, parents should be aware of their roles and responsibilities, as one's relationship with his/her own family is critical in the individual's life cycle.

Although the significance of the relationship with parents in the childhood and the adulthood of the child is known (Bowlby, 1969; Erikson \& Erikson, 2014; Ford, 2006), the situation affects the person's psychological development in the lifetime (Boszormenyi-Nagy \& Spark, 1973; Gültekin, 2010). Many scientists such as Adler (2002), Bowlby (1969), Erikson and Erikson (2014), and Freud (2015) also highlight the pattern of relationship in the family and drew attention to its impact on the formation of the personality. The influence of relationships with the family of origin also reveals itself during individuals' marriage and in marital conflicts they experienced (Lower, 2005). Glasser and Glasser (1995) underline that married individuals behave in their own marriage as they learn from their parents and their relationship styles can be evaluated as the repetition of behavior patterns in their family of origin (cited as Nazl1, 2014). Parentification was a significant predictor of personality types (Wells \& Jones, 1999). Since Sroufe, Cooper and Dehart (1996) state that childhood personality traits played an important role in marital satisfaction. The parentification influences the individual and the person's family, spouse, or the individuals' relationship with their children and methods of childcare-education (Özabac1, 2011; Valleau, Bergner \& Horton, 1995). People burden the values, beliefs, positive and negative qualifications what they brought from the family of origin to their marriage (İşmen-Gazioğlu, 2011). Bagget, Shaffer and Muetzelfed (2015) state that girls' relationship with their father affects their romantic relationship in adulthood. On the other hand, Peris, Goeke-Morey, Cummings, and Emery (2008) compared the marital life of the parents with the parentification levels of their children, and the parentification level of the children of the couples who had conflict in their marriages was also found to be high. It is a finding parallel to the results of Feldman, Fisher and Seitel's (1997) study. There is no study examining a direct relationship between marital satisfaction and parentification. Therefore, it is crucial to examine the relationship between parentification and marital satisfaction. In this way, the role of the traces which people bring from their families (Özabac1, 2011) in their marriage life is examined.

Looking at the concept of parentification, Boszormenyi-Nagy and Spark (1973) cited that the system concept in the family and the members' roles were the reciprocatively dependent distribution; they also emphasized the importance of fulfilling the roles and responsibilities burdened by each family member. Jones and Wells (1996) explained that parents left their roles and responsibilities in a way that is not appropriate for their children's development as an extreme boundary violation. The role reversal occurring while being compelled to act as a parent to their parents or siblings results in "parentification". The children may utilize to fulfill the alienated parents' emotional life (Hooper \& Wallace, 2009; Minuchin, Montalvo, Guerney, Rosman, \& Schumer, 1967). Further, the skewness of parent-child roles is also observed (Chase, 1999), and "parentified children", which also bear the costs associated with the development of their parents, arises (Jurkovic, 1997). Azar and Wolfe (1998) have 
considered parentification as child neglect or even as abuse. Jurkovic, Morrell, and Thirkield (1999) define this stiuation as destructive parentification. Furthermore, it ignores the emotional development of the child and affects the relationship style in adulthood (Hooper, 2007). Burton et al. (2018) also examined the relationship between parentification and depression in this context. There are also studies analayzing the relationship between depression and parentification (e.g., Derikozis \& Wingsiong, 2017; Yıldırım, 2016; Köyden, 2015; Hooper, Doehler, Jankowski, \& Tomek, 2012). It is significant to examine the relationship between parentification and depression because it causes possible consequences.

Parentification, which can be counted on the family traces of origin, has a significant effect on marital satisfaction and mental health. Many possible conditions such as depression, psychological stress, anxiety, eating disorders, embarrassment, adaptation problems, substance use, low self-esteem, and socioeconomic problems are known to be related to parentification (Burnett, Jones, Bliwise, \& Ross, 2006; Chase, Deming, \& Wells, 1998; Earley \& Cushway, 2002; Fitzgerald, 2005; Hooper \& Wallace, 2009; Jones \& Wells, 1996). Besides, parentification affects individuals' depression levels (Carroll \& Robinson, 2000; Hooper, Doehler, Jankowski, \& Tomek, 2012; Jurkovic, 1997; Sfoggia, Pacheco, \& Grassi-Oliveira, 2008; Yıldırım, 2016). Furthermore, there are fewer studies studying on correlational researches between parentification and personal/familial qualifications (Fitzgerald, Schneider, Salstrom, Zinzow, Jackson, \& Fossel, 2008; McMahon \& Luthar, 2007; van der Mijl \& Vingerhoets, 2017). Especially, in Turkey, studies on parentification and the factors influencing parentification are much less common. Since the concept of parentification as a concept that can change according to ethnic and cultural influences (Chase, 1999), in this study, the concept of parentification was considered to be a concept with predominant cultural aspects and was defined in terms of individuals' personal and familial characteristics. Consequentially, it is important to examine the relationship among levels of parentification, marital satisfaction, and depression of married individuals as well as the examination of their personal and familial qualifications.

\section{Purpose}

Kagitcibasi, Sunar, and Bekman (2001) indicated that the boundaries in the family of origin were not mature enough and children's autonomy was disregarded in Turkey. Conversion to a nuclear family from an extended family in Turkey has been continuing. Thus, boundaries in the family have a permeable structure, and it is critical to search this situation. Significantly, family members know their roles and responsibilities and fulfill their responsibilities and duties appropriate for their development. Due to parentification, the family's boundaries become miscible, and a negative situation arises (Chase, 1999). As a result, uncertainness of family boundaries in Turkey leads to parentification. Hence, investigating the concept of parentification and sharing the results of the studies are worthwhile. Further, the relationship with the spouses' family of origin is also significant in Turkey based on collectivist culture. It is possible to see that this situation is reflected even in proverbs and idioms in the culture and has such a social dynamic (Alkayış, 2013; Koç, 2016). Furthermore, individuals' relationship with their parents has a great importance in their childhood experiences. Therefore, as it is thought that familial and personal characteristics might affect depression, the personal and familial characteristics of the individuals, this study were determined in line with the studies in the literature (Castro, Jones, \& Mirsalimi, 2004; Danby et al., 2015; Earley \& Cushway, 2002; Hooper, 2008; Leon \& Rudy, 2005; Lewandowska-Walter, Borchet, Rostowska, Polomski, \& Peplinska, 2017). Thus, it is also wondered how the parentification, which is "silver spoon", impacts married individuals. In addition, owing to the absence of articles investigating parentification of married adults, the concept needs to be explained. This study aims to investigate the relationship among levels of parentification, depression, and marital 
satisfaction of married people as well as the examination of their personal and family qualities affecting their parentification levels.

\section{Method}

\section{Research Method}

This correlational study examines the relationship among the variables (Karasar, 2000), and includes a cross-sectional research method in survey models.

\section{Participants}

This study's data were obtained from 671 married people (265 men, 406 women) residing in Ankara. When the requirement of "being married for at least one year" was applied, data were collected from 597 married individuals (244 men, 353 women). The participants were formed through a convenience sampling method (Fraenkel, Wallen \& Hyun, 2012). The demographic information (was collected to determine the participants' characteristics) of the participants was presented in Table 1.

Table 1. The Participants' Demographic Information

\begin{tabular}{|c|c|c|c|}
\hline & & Frequency (n) & Percentage (\%) \\
\hline \multirow{2}{*}{ Gender } & Men & 244 & 40.9 \\
\hline & Women & 353 & 59.1 \\
\hline \multirow{4}{*}{ Age } & 29 years and younger & 123 & 20.6 \\
\hline & $30-39$ & 238 & 39.9 \\
\hline & $40-49$ & 134 & 22.4 \\
\hline & 50 years and older & 102 & 17.1 \\
\hline \multirow{13}{*}{ Occupation } & Academician & 21 & 3.5 \\
\hline & Worker & 118 & 19.8 \\
\hline & Advocate & 6 & 1.0 \\
\hline & Banking worker & 9 & 1.5 \\
\hline & Soldier & 4 & 0.7 \\
\hline & Civil servant & 95 & 15.9 \\
\hline & Doctor & 5 & 0.8 \\
\hline & Retired & 30 & 5.0 \\
\hline & Businessperson & 47 & 7.9 \\
\hline & Housewife & 145 & 24.3 \\
\hline & Unemployed & 7 & 1.2 \\
\hline & Engineer & 18 & 3.0 \\
\hline & Teacher & 92 & 15.4 \\
\hline \multirow{4}{*}{ Duration of Marriage } & $0-5$ & 177 & 29.6 \\
\hline & $6-15$ years & 199 & 33.3 \\
\hline & $16-25$ years & 124 & 20.8 \\
\hline & 26 years and over & 97 & 16.2 \\
\hline \multirow{4}{*}{ Number of Children } & Absence & 90 & 15.1 \\
\hline & One child & 270 & 45.2 \\
\hline & Two children & 145 & 24.3 \\
\hline & Three children and over & 92 & 15.4 \\
\hline
\end{tabular}

\section{Ethics Committee Approval Notification}

This study was carried out in accordance with the approval of Hacettepe University Ethics Committee dated July 17, 2018 and numbered 35853172-300. 


\section{Data Collection Tools}

\section{The Personal Information Form}

It was developed by the researcher and contains several questions about the participants' family of origin and personal information.

\section{Parentified Child Scale - Adult Form (PCS-A)}

Zencir and Haskan-Avc1 (2019) developed this scale. The scale has two sub-dimensions that explain the level of general parentification (22 items) and sibling-oriented parentification (10 items). In this study, only the first dimension (parentification) was utilized. All items of the scale are based on both retrospective memories and current experiences. "It was expected of me to alleviate my mother's /father's worries" can be an example for the items. The internal consistency coefficient of parentification sub-dimensions of the scale was calculated as .88. The total variance explained by the parentification sub-dimension of the scale was $59.52 \%$. In this study, "parentification" scores were only used, and the internal consistency coefficient in this study was analyzed as .88. Confirmatory factor analysis of the general parentification with 22 items showed RMSEA=.073; CFI=.95; NFI=.92. In addition, the correlation coefficient of the relationship between Filial Responsibility Scale and PCS-A was analayzed as .81. The test-retest correlation coefficient was .91.

\section{Beck Depression Scale (BDS)}

It was developed by Beck (1961) to measure the depression level of individuals and adapted to Turkish culture by Hisli (1988). In each item, individuals were given four sentences reflecting their moods and asked to mark one of appropriate options for these moods. It is a scale rated as 0 to 3 Likerttype. The internal consistency coefficient of the scale was calculated as .80 . Similar scale validity of BDS was based on the depression scala (D) of the MMPI. The correlation coefficient between BDS and MMPID scale was found .63 (Hisli, 1988). Additionally, Hisli's (1989) other study found that the Pearson correlation coefficient between BDS and MMPI-D was as .50 and total common variance of the BDS was as $\% 58$ for all group (depressive people and students) and as \%41.6 for the university students. The internal consistency coefficient in the current study is .88 .

\section{The Marital Satisfaction Scale (MSS)}

It was developed by Çelik and Yazgan-İnanç (2009) to measure the marital satisfaction of individuals, and the scale has 3 subdimensions such as family, sexuality, and self. Also, the scale has 13 items, and 8 of which are reverse items. The scale is A 5-point Likert type. The highest score to be obtained from the scale is 65 , and the lowest score is 13 . High scores indicate the high level of marital satisfaction of married people. The total variance explained by the scale is $49.23 \%$. The internal consistency coefficient of the "family" subscale, one of the subscales of the scale, is .83; "Sexuality" was calculated as .81 and "self" as .75. Criterion-related validity study was analyzed with Beck Depression Scale and Marriage Adjustment Scale. A significant negative correlation was found with BDI $\left(\mathrm{r}=-.44^{* *}\right)$. The internal consistency coefficient in the current study was .84 on the "family" subscale; It was analyzed as .91 for the "sexuality" subscale and .76 for the "self" subscale.

\section{Data Collection}

The data were obtained from participants living in Ankara, both online and face to face. After the informed consent form was given from the participants, their voluntary participation was expected. It was stated that they have the opportunity to leave and stop working whenever they want. 


\section{Data Analysis}

The relationship between marital satisfaction, depression, and parentification levels was examined through the Pearson correlation coefficient and linear regression analysis. Besides, the main effect of the married individual's personal and family qualifications on the levels of parentification was investigated by using the Two-Way analysis of variance (ANOVA). In this section, it was first examined whether the collected data showed a normal distribution. The kurtosis-skewness values were found to be between -2 and +2 and it was decided to use parametric tests (George \& Mallery, 2010). In addition, according to the result of Levene' Test, it was seen that the data were normally distributed.

\section{Results}

\section{Examining the Relationship among Marital Satisfaction, Parentification, and Depression Levels of Married Individuals}

Analysis results related to descriptive statistics and correlation coefficients related to marital satisfaction, depression, and parentification levels of married individuals are presented in Table 2.

Table 2. Descriptive Statistics ( $\bar{x}$, ss, Pearson Correlation Coefficients)

\begin{tabular}{lcccc}
\hline Variables & $\overline{\boldsymbol{x}}$ & ss & $\mathbf{1}$ & $\mathbf{2}$ \\
\hline 1. Parentification & 53.91 & 16.06 & & \\
2. Marital Satisfaction & 32.72 & 14.64 & $-.39^{*}$ & \\
3. Depression & 12.90 & 9.15 & $.22^{*}$ & $-.11^{*}$ \\
\hline
\end{tabular}
${ }^{*} p<.01$

In Table 1, the mean scores and standard deviation values of variables are 53.91 for the parentification levels, 12.90 for depression levels and 32.72 for marital satisfaction levels. Besides, when the correlation coefficients of the variables are analyzed, there is a statistically negative relationship between parentification and marital satisfaction levels. Also, there is a statistically significant relationship between parentification and depression levels. Regression analysis results for parentification and depression levels predicting marital satisfaction are shown in Table 3. Therefore, while marital satisfaction is the dependent variable, parentification and depression are the independent variables. In the regression analysis, parentification and depression variables as the independent variables were analyzed respectively, and the Enter model was selected in the analysis.

Table 3. Regression Analysis Results on Parentification and Depression Predicting Marital Satisfaction

\begin{tabular}{llllllll}
\hline Dependent Variable & Predictors & $\beta$ & S.E. & $\mathbf{R}$ & $\mathbf{R}^{2}$ & $t$ & $\boldsymbol{F}$ \\
\hline \multirow{3}{*}{ Marital Satisfaction } & Constant & & 1.97 & & & $26.45^{*}$ & \\
& Parentification & -.38 & .04 & .39 & .15 & $-9.93^{*}$ & \multirow{2}{*}{$53.65^{*}$} \\
& Depression & -.02 & .06 & .11 & .01 & -.73 & \\
\hline
\end{tabular}

While examining the $t$-test results related to the significance of the regression coefficients in Table 3, it is seen that the parentification levels predict marital satisfaction $(t=9.93, p=.00)$. However, the level of depression does not predict marital satisfaction $(t=-.73, p=.47)$. When the regression analysis results are examined, it is seen that the parentification levels explain $15 \%$ of the variance in the marital satisfaction levels.

Table 2 also shows that there is a positive, statistically relationship between parentification and depression levels. Regression analysis results for that parentification predicted marital satisfaction are presented in Table 4. 
Table 4. Regression Analysis Results on Depression Predicting Parentification

\begin{tabular}{llllllll}
\hline Dependent Variable & Predictors & $\beta$ & S.E. & $\mathrm{R}$ & $\mathrm{R}^{2}$ & $t$ & $F$ \\
\hline & Constant & & 1.28 & & & $4.76^{*}$ & \\
Parentification & Depression & .12 & .02 & .22 & .05 & $5.37^{*}$ & $28.84^{*}$ \\
\hline${ }^{*} p<.01$ & & & & & & &
\end{tabular}

Regression analysis results present that depression predicts parentification $(\mathrm{t}=4.76, \mathrm{p}<.01)$. When the results in Table 4 are examined, it is seen that the parentification levels explain $5 \%$ of the variance in the depression levels.

\section{Findings Regarding the Investigation of the Difference among Parentification Levels according to Family Characteristics of Married Individuals}

Two-way analysis of variance (ANOVA) was tested according to the familial qualifications of married individuals.

Table 5. Two-way Analysis of Variance (ANOVA) Results Regarding the Investigation of the Difference among Parentification Levels according to Family Characteristics of Married Individuals

\begin{tabular}{lccccccc}
\hline Variables & $\begin{array}{c}\text { Sum of } \\
\text { Squares }\end{array}$ & $d f$ & $\begin{array}{c}\text { Mean of } \\
\text { Squares }\end{array}$ & $\boldsymbol{F}$ & $p$ & $\eta^{2}$ \\
\hline Chronic illness of family members & 1889.743 & 1 & 1889.743 & 8.335 & $.004^{*}$ & .02 \\
Spending time with the parents & 5581.935 & 1 & 5581.935 & 24.621 & $.000^{*}$ & .04 \\
Substance abuse status of the parents & 1109.287 & 1 & 1109.287 & 4.893 & $.027^{*}$ & .01 \\
Father's employment status & 1720.474 & 2 & 860.237 & 3.794 & $.023^{*}$ & .01 \\
Mother's employment status & 87.118 & 2 & 43.559 & 0.192 & .825 & .01 \\
$\begin{array}{l}\text { One of the parents working outside the } \\
\text { province }\end{array}$ & 1039.976 & 1 & 1039.976 & 4.587 & $.033^{*}$ & .01 \\
$\begin{array}{l}\text { Substance abuse status of family members* } \\
\text { Father's employment status }\end{array}$ & 854.887 & 2 & 427.443 & 1.885 & .153 & .01 \\
$\begin{array}{l}\text { Substance abuse status of family members* } \\
\text { Mother's employment status }\end{array}$ & 147.205 & 2 & 73.602 & 0.325 & .723 & .01 \\
$\begin{array}{l}\text { Chronic illness of family members* } \\
\text { Mother's employment status }\end{array}$ & 88.407 & 2 & 44.203 & 0.195 & .823 & .01 \\
\hline
\end{tabular}

${ }^{*} p<.05$

Table 5 shows that, according to chronic illness of family members $(\mathrm{F}=8.335, \mathrm{p}<.05)$, spending time with parents $(\mathrm{F}=24.621, \mathrm{p}<.05)$, substance abuse status of the parents $(\mathrm{F}=4,893, \mathrm{p}<.05)$, father's employment status $(\mathrm{F}=3.794, \mathrm{p}<.05)$ and one of the parents working outside the province $(\mathrm{F}=4.587, \mathrm{p}<$ .05), there is a significant difference in the parentification levels of married individuals. According to the results of multi-directional variance analysis, these variables make a statistically significant difference. However, there is no statistically significant difference in their mothers' employment status $(\mathrm{F}=0.192, \mathrm{p}>.05)$. Besides, in terms of interaction both substance abuse status of family members and his father's employment status $(\mathrm{F}=1.885, \mathrm{p}>.05)$; interaction both substance abuse status of the parents and the mother's employment status $(\mathrm{F}=0.325, \mathrm{p}>.05)$; interaction both chronic illness of family members and mother's employment status $(\mathrm{F}=0.195, \mathrm{p}>.05)$; there is not a statistically significant difference on parentification scores. For the analysis, eta - square ( $\eta 2)$ values vary between .01 and .04 . 
The Tukey test was also carried out to determine the source of the characteristics that have the main effect on parentification levels.

Table 6. Tukey HSD Test Results Regarding the Analysis of Differences in Parentification Level according to Chronic Illness of Family Members

\begin{tabular}{llcccc}
\hline $\begin{array}{l}\text { Dependent } \\
\text { variable }\end{array}$ & Variables & $n$ & $\bar{x}$ & $\begin{array}{c}\text { Difference between } \\
\text { means (Yes-No) }\end{array}$ & $p$ \\
\hline Parentification & Chronic illness (Yes) & 140 & 63.56 & 5.22 & $.00^{*}$ \\
\hline
\end{tabular}

${ }^{*} p<.05$

According to Table 6, the parentification score of married individuals with permanent illness (psychological, physiological, and so on) of their parents or siblings is higher than the parentification scores of married persons who do not have the family members with chronic illness. The difference between the mean scores is statistically significant according to the Tukey test result $(p<.05)$. In the light of the results, while the mean of parentification levels of individuals who have a family member with a chronic illness is analyzed as 63.56, the mean of parentification scores of others are 58.34. The difference between the mean scores was analyzed and found statistically significant (Table 7).

Table 7. Results of Comparing Means of Parentification Levels of the Married Individuals according to the Status of the Spending Time Their Parents

\begin{tabular}{llcccc}
\hline $\begin{array}{l}\text { Dependent } \\
\text { variable }\end{array}$ & Variables & $n$ & $\overline{\boldsymbol{x}}$ & $\begin{array}{c}\text { Difference between } \\
\text { means (Yes-No) }\end{array}$ & $\boldsymbol{p}$ \\
\hline \multirow{2}{*}{ Parentification } & $\begin{array}{l}\text { Spending time with } \\
\text { the parents (Yes) } \\
\begin{array}{l}\text { Spending time with } \\
\text { the parents (No) }\end{array}\end{array}$ & 279 & 57.57 & & \\
& 268 & 64.33 & -6.76 & $.00^{*}$ \\
\hline${ }^{*} p<.05$ & & & &
\end{tabular}

While examining Table 7, the parentification scores of the individuals who frequently spend time with their parents and who have frequent experience sharing are lower than those of the individuals who do not share this experience frequently, and those who spend less time. This difference between the means is statistically significant $(\mathrm{p}<.05)$. Parentification scores of those who often share experiences with their parents and spend time are 57.57, while those who spend less time have a parentification score of 64.33 (Table 7).

Table 8. $\bar{x}$ and $n$ Values according to the Father's Employment Status of Married People

\begin{tabular}{|c|c|c|c|}
\hline Variables & Father's employment status & $\bar{x}$ & $n$ \\
\hline \multirow{3}{*}{ Parentification } & Father has never worked & 66.36 & 20 \\
\hline & $\begin{array}{l}\text { Your father worked in an income- } \\
\text { generating job, even if he did not } \\
\text { regularly work }\end{array}$ & 61.20 & 132 \\
\hline & $\begin{array}{l}\text { Your father has always worked in a job } \\
\text { that generates regular income }\end{array}$ & 55.29 & 395 \\
\hline
\end{tabular}

According to Table 8, the mean of scores of parentification of the children of the people whose father is not working in a job that never generates regular income is 66.36; the mean of the people whose father has worked in a job changefully is 61.20 , and the mean of the people whose father always works in a job is 55.29 . 
Table 9. Tukey HSD Test Results Regarding the Analysis of the Differences in Parentification Levels According to the Father's Employment Status of Married Individuals

\begin{tabular}{|c|c|c|c|c|}
\hline $\begin{array}{l}\text { Dependent } \\
\text { Variable }\end{array}$ & $\begin{array}{l}\text { Father's Employment } \\
\text { Status (I) }\end{array}$ & $\begin{array}{l}\text { Father's Employment } \\
\text { Status (J) }\end{array}$ & $\begin{array}{c}\text { Difference } \\
\text { between means } \\
\text { (I-J) }\end{array}$ & $p$ \\
\hline \multirow{3}{*}{ Parentification } & \multirow[t]{2}{*}{ Father has never worked. } & $\begin{array}{l}\text { Your father worked in an } \\
\text { income-generating job, } \\
\text { even if he did not } \\
\text { regularly work }\end{array}$ & 5.16 & .33 \\
\hline & & $\begin{array}{l}\text { Your father has always } \\
\text { worked in a job that } \\
\text { generates regular income }\end{array}$ & $11.07^{*}$ & $.02^{*}$ \\
\hline & $\begin{array}{l}\text { Your father worked in an } \\
\text { income-generating job, } \\
\text { even if he did not } \\
\text { regularly work }\end{array}$ & $\begin{array}{l}\text { Your father has always } \\
\text { worked in a job that } \\
\text { generates regular income }\end{array}$ & 5.91 & .09 \\
\hline
\end{tabular}

In Table 9, there is no statistically significant difference between the mean scores of married people whose fathers have never worked and those who work in an income-generating job even if their father does not regularly work ( $p>$.05). However, the difference between the parentification score of those whose father has never worked and the parentification level of those whose father has always worked in a job that generates regular income is statistically significant $(\mathrm{p}<.05)$. Also, the difference between the parentification level of people whose father has always worked in a job that generates regular income, even if their father does not regularly work, is not statistically significant ( $p>.05)$.

In Table 10, the mean of the parentification score of married individuals, stating that at least one of the parents works outside the province, is 62.54. Those who stated that they did not work outside the province are calculated as 59.36. According to the analysis results, the presence and absence of at least one of his parents outside the province during childhood and adolescence has a main effect on parentification scores $(\mathrm{p}<.05)$.

Table 10. $\bar{x}$ and $n$ Values according to one of the Married People's Parents Working Outside the

Province

\begin{tabular}{lcccccc}
\hline $\begin{array}{l}\text { Dependent } \\
\text { variable }\end{array}$ & $\begin{array}{c}\text { One of the married } \\
\text { people's parents } \\
\text { working outside the } \\
\text { province }\end{array}$ & $n$ & $\bar{x}$ & $\begin{array}{c}\text { Difference between } \\
\text { means (Yes-No) }\end{array}$ & $p$ \\
\hline Parentification & Yes & 149 & 62.54 & 3.17 & $.03^{*}$ \\
\hline
\end{tabular}

${ }^{*} p<.05$

According to Table 10, there is a statistically significant difference between the levels of parentification of married people per the status if married individuals' parents work outside the province $(\mathrm{p}<.05)$. Married individuals whose parents work outside the province have higher parentification scores than others. 


\section{Investigation of the Difference between Parentification Levels according to the Personal Qualifications of Married Individuals}

Two-way analysis of variance (ANOVA) was tested according to the personal qualifications of married individuals.

Table 11. Two-way Analysis of Variance (ANOVA) Results Regarding the Investigation of the Difference among Parentification Levels according to Personal Characteristics of Married Individuals

\begin{tabular}{lcccccc}
\hline Variables & $\begin{array}{c}\text { Sum of } \\
\text { Squares }\end{array}$ & $d f$ & $\begin{array}{c}\text { Mean of } \\
\text { Squares }\end{array}$ & $\boldsymbol{F}$ & $p$ & $\eta^{2}$ \\
\hline Gender & 54.973 & 1 & 54.973 & 0.234 & .63 & .00 \\
Number of siblings & 2851.090 & 3 & 950.363 & 4.040 & $.01^{*}$ & .02 \\
Birth order & 271.065 & 3 & 90.355 & 0.384 & .77 & .00 \\
Settlement Unit & 123.158 & 2 & 61.579 & 0.262 & .77 & .00 \\
Condition of working in childhood & 10154.453 & 1 & 10154.453 & 43.166 & $.00^{*}$ & .07 \\
Number of siblings*Gender & 565.351 & 3 & 188.450 & 0.801 & .49 & .00 \\
Birth Order*Gender & 260.122 & 3 & 86.707 & 0.369 & .78 & .00 \\
Gender Condition of working in childhood & 632.028 & 1 & 632.028 & 2.687 & .10 & .01 \\
Settlement unit ${ }^{*}$ Gender & 359.996 & 2 & 179.998 & 0.765 & .47 & .00 \\
\hline${ }^{*} p<.05$ & & & & & &
\end{tabular}

According to Table 11, although there is no statistically significant difference in parentification levels according to the individual characteristics such as the gender of married individuals $(\mathrm{F}=0.234$, $\mathrm{p}>.05)$, the order of birth $(\mathrm{F}=0.384, \mathrm{p}>.05)$, the settlement unit where he spent most of his life $(\mathrm{F}=0.262$, $\mathrm{p}>.05)$, the common impact of the number of siblings and gender $(\mathrm{F}=0.801, \mathrm{p}>.05)$, the common effect of the birth order and gender $(\mathrm{F}=0.369, \mathrm{p}>.05)$, the common effect of gender and employment status as a child $(\mathrm{F}=2.687, \mathrm{p}>.05)$ of the settlement and gender $(\mathrm{F}=0.765, \mathrm{p}>.05)$; It has a statistically significant effect on parentification levels according to other personal qualifications such as the number of siblings $(\mathrm{F}=4.040, \mathrm{p}<.05)$ employment status $(\mathrm{F}=43.166, \mathrm{p}<.05)$. While the eta square effect size of the number of siblings shows the moderate effect size $(\eta 2=.02)$, the eta square effect size $(\eta 2=.07)$ of the employment status during childhood is at a moderately strong level.

Table 12. $\bar{x}$ and $n$ Values according to the Number of Siblings of the Participants

\begin{tabular}{llcc}
\hline Variable & The number of siblings & $\overline{\mathrm{X}}$ & $\mathrm{n}$ \\
\hline \multirow{3}{*}{ Parentification } & 2 or fewer & 50.35 & 156 \\
& 3 siblings & 52.05 & 151 \\
& 4 siblings & 55.97 & 117 \\
& 5 and more & 57.36 & 173 \\
\hline
\end{tabular}

According to the number of siblings of married individuals in Table 12, in the parentification scores, the lowest average score belongs to the group with 2 or fewer siblings $(\bar{x}=50.35)$. The second smallest parentification level is in individuals with 3 siblings $(\overline{\mathrm{X}}=52.05)$. While 4 siblings $(\overline{\mathrm{X}}=55.97)$ are the third smallest average, individuals with 5 or more siblings show the highest average $(\bar{X}=57.36)$. 
Table 13. Tukey HSD Test Results Regarding the Analysis of the Differences in the Parentification Level according to the Number of Siblings of Married Individuals

\begin{tabular}{lllcc}
\hline $\begin{array}{l}\text { Dependent } \\
\text { variable }\end{array}$ & $\begin{array}{l}\text { The number of } \\
\text { siblings (I) }\end{array}$ & $\begin{array}{l}\text { The number of } \\
\text { siblings (J) }\end{array}$ & $\begin{array}{c}\text { Difference between means } \\
(\mathbf{I}-\mathrm{J})\end{array}$ & $\mathbf{p}$ \\
\hline \multirow{4}{*}{ Parentification } & \multirow{3}{*}{2 or fewer } & 3 siblings & -1.7004 & .77 \\
& & 4 siblings & $-5.6132^{*}$ & $.02^{*}$ \\
\cline { 2 - 5 } & \multirow{2}{*}{3 siblings } & 5 and more & $-7.0058^{*}$ & $.00^{*}$ \\
\cline { 2 - 5 } & \multirow{2}{*}{4 siblings } & 5 siblings & -3.9128 & .16 \\
$* p<.05$ & 5 and more & $-5.3054^{*}$ & $.01^{*}$ \\
\hline
\end{tabular}

Tukey HSD test is conducted to determine the source and effect of the difference among the means, and the results are presented in Table 13. The mean difference between the group with 2 or fewer siblings and the group with 3 siblings is not statistically significant ( $p>.05$ ). The mean difference between 2 or less with 4 siblings and 5 or more siblings is statistically significant $(p<.05)$. The parentification levels of the individuals with 4 siblings and individuals with 5 or more siblings are higher than those of the individuals with 2 or fewer siblings, and this difference is statistically significant $(\mathrm{p}<.05)$. On the other hand, although the mean difference between the groups with 3 siblings and 4 siblings is not statistically significant ( $p>.05)$, there is a significant difference between the group with 5 and more siblings $(p<.05)$. The mean difference between the 4 siblings and the group of 5 and more is not statistically significant ( $p>.05)$.

Table 14. Tukey HSD Test Results Regarding the Analysis of the Differences in the Parentification Level according to the Condition of Working in the Childhood of Married Individuals

\begin{tabular}{llcccc}
\hline $\begin{array}{l}\text { Dependent } \\
\text { variable }\end{array}$ & $\begin{array}{l}\text { Condition of working } \\
\text { in childhood }\end{array}$ & $\boldsymbol{n}$ & $\overline{\boldsymbol{x}}$ & $\begin{array}{c}\text { Difference between } \\
\text { means (Yes-No) }\end{array}$ & $\boldsymbol{p}$ \\
\hline Parentification & Yes & 295 & 57.743 & 9.070 & $.00^{*}$ \\
& No & 302 & 48.673 & & \\
\hline
\end{tabular}

${ }^{*} p<.05$

In the light of the results in Table 14, it is observed that the participants with the highest parentification level belong to the group of the condition of working in a job as a child $(\bar{x}=57.74)$. Married individuals who answered "no" for their employment status have lower parentification levels $(\bar{X}=48.68)$. The parentification scores of the group working in a job as a child are higher than those of the non-working group, and this difference is statistically significant $(p<.05)$. Employment status as a child from the personal characteristics of the participants also has a statistically main effect on parentification scores $(p<.05)$ (Table 14).

\section{Discussion and Conclusion}

\section{The Results Regarding the Levels of Parentification and Marital Satisfaction of Married Individuals}

As a result of this study, there is a statistically significant relationship between levels of parentification and marital satisfaction of married individuals. The parentification levels predict statistically marital satisfaction levels. Correlatively, when the parentification levels decrease, the marital satisfaction levels increase. In other words, married people's parentification levels play a significant role in their own marital relationships. Furthermore, it can be said that individuals' 
relationship style in their own family of origin maintains in their marriage life and that the background in the family of origin has an impact (Özabac1, 2011). Boszormenyi-Nagy (1987) also states that people who see that the boundaries in their family of origin were permeable and imbalance might also have trouble in their own marital relationship. Though parentification and marital satisfaction have not been studied before, their romantic relationship satisfaction has been investigated. In a study, which had similar findings with this study, on female university students, a significant relationship has been found negatively between the parentification levels with the fathers and romantic relationship satisfaction of the females (Bagget et al., 2015). When considered from this point of view, there is a significant relationship between the concepts emphasizing the relationship quality and the level of depression, and this study has reached similar results with the literature (Bagget et al., 2015; Boszormenyi-Nagy, 1987; Madden \& Shaffer, 2016; Peris et al., 2008). The reason for a common result within the scope of this study may be the social support received from another person or institution in their social-ecological system, even if they are the parentified children in their own family of origin. The condition can be effective and allow them to follow a positive course.

\section{The Results Regarding Parentification Levels and Depression Levels of Married Individuals}

There is a statistically significant relationship between depression levels and parentification levels, and parentification level predicts depression statistically. Thus, it can be said that the level of parentification had the main effect on depression levels. This result is supported by similar literature results (Burton et al., 2018; Carroll \& Robinson, 2000; Derikozis \& Wingsiong, 2017; Hetherington, 1999; Hooper \& Wallace, 2009; Köyden, 2015; Yıldırım, 2016). Emre (2016) also states that parentification would have a negative effect on the emotional and psychological structure of the person. Parentification also influences the child's spiritual development and has a protective or destructive legacy (Celano, 2018). Therefore, the result of this research may also be presumptive. Parentified children spend a significant part of their power on the path to becoming the parent of their parents and may also experience more feelings of fatigue, exhaustion, and boredom. Heubeck, Tausch, and Mayer (1995) also state that children taking responsibility for their parents also had a burden which may cause depression.

\section{Married Individuals' Family Characteristics and Effects on the Parentification Levels}

\section{The Relationship between the Condition of Chronic Illness of Family Members and the Parentification Levels}

There is a significant difference in parentification level according to the presence/absence of a person with chronic illness in the family. The mean of the parentification score of the participants who grew up in a family with a permanent illness family member is higher than that of the other participants. Having a family member with permanent illness has the main effect on the level of parentification, and, likely, the child may also be parentified in such a family (Lamorey, 1999). Individuals who were the parentified children tend to do kindness and are also often found in altruistic behavior (Stalfa-Jr., 1994). Additionally, similar results are obtained in a study with individuals with and without parents with AIDS (Stein, Riedel, \& Rotheram-Borus, 1999; Stein, Rotheram-Borus, \& Lester, 2007). Despite these results, Shifren (2001) states in his study that individuals whose parents had a permanent illness are stronger throughout their lives if they are an early caregiver. Such parentification has a positive effect. It can be said that the positive aspects of parentification could be in the part of instrumental parentification, and in cases where the child felt approved and emotionally loved by the parent (Hooper, 2007). In light of all these results, if one of the parents in the family of origin has chronic discomfort, 
these parents' parental support, ability, and capacity may weaken due to illness, and parentification will also occur negatively.

\section{The Relationship between Married Individuals' Spending Time with the Parents and Parentification}

Parentification scores of married individuals who spent time with their parents on weekends are lower than those of the ones who did not spend time with their parents on weekends. Spending time with parents has a main effect on their level of parentification, and more time spending may reduce the level of parentification. The literature is seen as a critical concept for family members to spend time with each other, spending quality time is reflected positively (Prime Ministry General Directorate of Family and Social Research, 2010). From this point of view, parents spending time with their children and sharing their experiences prevents children's parentification phenomenon. It is also significant that the parent used her parenting skills at full capacity by fulfilling her/his roles and responsibilities. In this context, Davis, Bilms, and Suveg (2017) state that a qualified and healthy parent-child relationship should provide positive contributions to the child's development and that it is important for the parent to be qualified so that they can become qualified parents.

\section{The Relationship between Substance Abuse Status of the Parents and the Parentification Levels}

The study has found a statistically significant difference between whether one of the study group's parents was addicted to drugs (alcohol, drugs, etc.) and their parentification levels. Individuals with a drug-addicted parent also have a high parentification level than those without a drug-addicted parent. The result was consistent with the previous findings (Burnett et al., 2006; Chase et al., 1998; Godsall, Jurkovic, Emshoff, Anderson, \& Stanwyck, 2004; Goglia, Jurkovic, Burt \& Burge-Callaway, 1992). Besides, the common effect of having a father's employment status and having a parent with substance abuse has been examined: there is no statistically significant difference in parentification levels. It is observed that there was no statistically significant difference between the mother's employment status and substance addiction status, and parentification levels.

In the literature, it is seen that having a substance abuser parent causes the parentification (Burnett et al., 2006; Godsall et al., 2004; Chase et al., 1998; Goglia et al., 1992; Jurkovic, 1997; Pasternak \& Schier, 2012) and people with alcoholic parents are more likely to be parentified as they are more responsible and more dependent on their families (Emre, 2016; Goglia et al., 1992; Pasternak \& Schier, 2012). In another study, a similar result is obtained, and it is found that those with high parentification were those whose parents were alcohol dependent (Godsall et al., 2004). On the other hand, a statistically significant difference between whether one of the study group' parents was addicted to drugs (alcohol, drugs, etc.) and their parentification levels has been not found. This may be due to the limited number of participants whose parents are addicted to substances.

\section{The Relationship between Employment status of Parents of Married Individuals and Parentification}

When the parentification level of married individuals according to the father's employment status is examined, a statistically significant difference is observed between the people who stated that their father was always working and those who stated that their father was never working. The parentification level of the participants, who stated that their father never worked, is higher than that of the married individuals who stated that their father was always working. Thus, the parentification 
level of the participants whose fathers regularly working is lower. Since the father's work brought along his roles and responsibilities, such a result may have come out.

While examining the mother's employment status of married people, there is no statistically significant difference between the parentification levels of married individuals. There is a main effect of the mother's employment status on parentification. The relationship between the socioeconomic level of the family and parentification has been investigated in the literature, although it is not related to the employment status of the mother and father (for example, Burnett et al., 2006; Haskan-Avc1, Zencir, Koç \& Tunç, 2018; Köyden, 2015; Wingsiong, 2015). When the literature is examined, it is known that disadvantaged and unfavorable living conditions and low economic level triggered parentification (Emre, 2016). Haskan-Avc1 et al. (2018) show that students in the lower economic had higher parentification levels. Burnett et al. (2006) also find a significant relationship between the household income level and the parent-child relationship in terms of the parenting skills affecting parentification. Furthermore, a positive relationship has been found between the mother's work outside the home and the parentification level (McMahon \& Luthar, 2007). Despite these results, both Wingsiong (2015) and Koyden (2015) do not detect an effect of the socio-economic level on the parentification.

\section{Married Individuals' Personal Characteristics and Their Effects on Parentification Levels}

\section{The Relationship between Gender and Parentification of Married Individuals}

In the current study, when male and female married individuals' parentification levels are examined, the difference between gender and parentification levels of married adults is not statistically significant. This result is supported by similar studies (Jurkovic, Thirkield, \& Morrel, 2001; van der Mijl \& Vingerhoets, 2017). However, in a study examining the relationship between the gender and parentification level of university students, it is seen that the parentification level of male students was higher than that of female students, so the difference is statistically significant (Hooper, Tomek, Bond, \& Reif, 2015). Furthermore, Clerici and Vanin (2002) find a significant difference between parentification levels in gender. On the other hand, Hetherington (1999) explains that the girls' emotional parentification levels were more than the boys'. However, in terms of instrumental parentification, the scores of the boys are higher.

Looking at the literature, a statistically significant difference in terms of gender is related to the different dimensions of parentification. Parentification has been examined in six different dimensions (emotional parentification focused on parents, instrumentation parentification focused on parents, emotional parentification focused on siblings, instrumental parentification focused on siblings, sense of injustice and, satisfaction with the role-taking); There is a statistically significant difference in gender in other dimensions besides the dimension of instrumental parentification focused on siblings (Lewansdowska-Walter et al., 2017).

In this study, there is no significant difference between the levels of parentification of married individuals and the development of parenting ability and capacity of their parents, regardless of the gender of the child, in families where there was parentification. Parentification has a multidimensional structure and been affected by the cultural factors. Therefore, there may not have been a significant difference. 


\section{The Relationship between the Number of Siblings of Married Individuals and Parentification Levels}

The level of parentification of married individuals shows a statistically significant difference in the number of siblings. Parentification levels of individuals with " 2 or less" siblings are lower than those of individuals with " 4 siblings" and " 5 and more", and this difference is statistically significant. Parentification levels of individuals with more siblings are also higher in terms of other groups. In other words, the parentification level of married people with more siblings in the family of origin is higher than that of the individuals who possess fewer siblings.

Haskan-Avc1 et al. (2018) conduct a study with university students; they achieve a similar result: the parentification level of the people with more siblings is higher. Another study analyzes that individuals with younger siblings had higher parentification levels than those without siblings (Wingsiong, 2015). Besides, McMahon and Luthar (2007) cite that the number of siblings in the family of origin affected the person's parentification level. They also state that the parentification level of people with more siblings was higher. In the literature, especially in parentification scales developed in recent studies, sibling dimensions and sibling relationships are also included in the scale items, which shows that the number of siblings and sibling relations are precious (Szymańska, 2021).

\section{The Relationship between Birth Order and Parentification Levels of Married Individuals}

No statistically significant difference in parentification levels of married individuals is found in this study. However, there is a significant relationship between being the eldest or first child and undertaking more care (Hetherington, 1999; McMahon \& Luthar, 2007). It emerges as a socio-cultural family system pattern, especially in societies where older children take on more responsibilities, especially being sisters or brothers and being parents. It turns out that being an older brother or sister takes on a possible task, such as having a younger brother or sister under certain responsibilities. For this reason, it is known that there was a statistically significant relationship between the order of birth and the responsibility to provide care, and older children have more responsibilities (Cuskelly \& Gunn, 2003). In this study, birth order does not have a main effect on parentification levels. This may be because the PCS-A used also has a sibling-focused parentification sub-dimension. Thus, even if there is a possible main effect, it may show itself in the other dimension of the scale. McMahon and Luthar (2007) state that the responsibilities of being a brother or sister were effective on the effect of the birth order on parentification. Since these relationships are also in a sub-dimension, the research scale may not have emerged in the parentification sub-dimension.

\section{The Relationship between Settlement Unit (Where Married Individuals Spend Most of Their Life) and Parentification Levels}

While investigating the relationship between parentification levels and the settlement unit where married individuals spend most of their lives, there is no statistically significant difference between them. This is the socio-cultural globalization of the world that results from social media, traditional mass media, and so on. Therefore, many situations in a big city can occur even in small cities and neighborhoods. The reduced gap between opportunities may have prevented it. It can be more important to evaluate the settlements from social and cultural aspects, not from the big-small concept. The absence of a statistically significant difference in the research results may be the determination of 
concepts such as metropolitan, city/district centers by only looking at the number of people living in that region.

\section{The Relationship between Employment status in Childhood and Parentification Level of Married Individuals}

The parentification levels of the participants working in a job as a child are higher than those of the participants who do not work in that period. This difference is also statistically significant. Working in a job to contribute to the income of the family of origin is considered a type of instrumental parentification (Chase, 1999; Jurkovic, 1997). It can be said that there are only positive aspects of instrumental parentification among the types of parentification. Valleau et al. (1995) also state that parentification might also positively affect a person's functional side and sense of responsibility. From these points of view, having a job in one's childhood may be a component of the parentification process. This result is parallel to the literature.

\section{Suggestions}

The relationship among the parentification levels, marital satisfaction, depression, and familialpersonal qualifications of married individuals was tried to be revealed. It is important that parents were aware of their roles and responsibilities and that the role reversal is in line with the child's developmental stages. A healthy family pattern also leads to the development of individuals' psychological resilience (Hooper, 2009). Although the importance of the relationship between the family of origin and parentification is known in the literature (Jurkovic, 1997), this study is expected to fill such a gap due to the limited number of studies. While the parent of the child develops the concept of parentification, it is important to determine both parents' parentification levels. Though the effects of parentification on the subsequent life periods of children are also examined, both the limited number and the absence of a study on marital life show the importance of this study. The results of this study indicate that parentification negatively affected marital satisfaction and triggered depression in adulthood. Moreover, the findings reveal individual and familial characteristics that impacted the parentification levels. Therefore, it is recommended to evaluate the results from such a perspective. It is significant to examine the family system and its borders with different samples since the Turkish society is particularly close to the sharing culture and the family and social relationships are "relationalconnected". Additionally, it is critical to conduct in-depth descriptive study results through qualitative interviews through the studies. Although the parentification is developed by the child's parent, it is also important to determine "the levels of parentifying" that will reveal how much and how parents do this. To develop the scale in this context may also contribute. In addition, although instant clinical depression level is measured in this research, it is recommended to measure depressive symptoms with personality traits and symptoms in future studies. It can be suggested that school psychological counselors report the risk factors of parentification according to their education level by presenting them in the context of the parent-child relationship. To illustrate, it is momentous to identify these students as well as to inform their parents about the parentification since students with more siblings may have higher parentification levels.

\section{Limitation}

The main limitation of the study may be the measurement of depressive symptoms instead of measuring clinical depression. For future studies, it may be more appropriate to measure depressive symptoms rather than clinical depression. In addition, some parts may not be discussed in depth in the 
discussion section, since the literature on parentification is not very deep and the concept has only just begun to be studied in the Turkish sample.

\section{References}

Adler, A. (2002). Sosyal duygunun gelişiminde bireysel psikoloji (H. Özgü, Trans.). İstanbul: Hayat.

Alkayış, M. F. (2013). Adıyaman yöresi atasözleri ve deyimlerinde gelin-kaynana ilişkisi ve evlilik konusu. International Periodical for the Languages, Listerature and History of Turkish or Turkic, 8(9), 579-594. Retrieved from https://arastirmax.com/en/system/files/dergiler/79199/makaleler/8/9/ arastirmax-adiyaman-yoresi-atasozleri-deyimlerinde-gelin-kaynana-iliskisi-evlilikkonusu.pdf.

Azar, S. T., \& Wolfe, D. A. (1998). Child physical abuse and neglect. In E. J. Mash \& R.A. Barkley (Eds.), Treatment of childhood disorders (2nd ed.) (pp. 501-544). New York: Guilford.

Bagget, E., Shaffer, A., \& Muetzelfeld, H. (2015). Father-daughter parentification and young adult romantic relationships among college women. Journal of Family Issues, 36(6), 760-783. https://doi.org/10.1177/0192513X13499759

Boszormenyi-Nagy, I. (1987). Foundations of contextual therapy: Collected papers of Ivan Boszormenyi-Nagy. MD. New York: Brunner/Mazel.

Boszormenyi-Nagy, I., \& Spark, G. M. (1973). Invisible loyalties. New York: Brunner/Mazel.

Bowlby, J. (1969). Attachment and loss: Vol.1 attachment. New York: Basic.

Bronfenbrenner, U. (1979). The ecology of human development: Experiments by nature and design. Harvard University.

Burnett, G., Jones, R. A., Bliwise, N. G., \& Ross, L. T. (2006) Family unpredictability, parental alcoholism, and the development of parentification. American Journal of Family Therapy, 34, 181-189. https://doi.org/10.1080/01926180600550437

Burton, L. (2007). Childhood adultification in economically disadvantaged families: A conceptual model. Family Relations, 56(4), 329-345. https://doi.org/10.1111/j.1741-3729.2007.00463.x

Burton, S., Hooper, L. M., Tomek, S., Cauley, B., Washington, A., \& Pössel, P. (2018). The mediating effects of parentification on the relation between parenting behavior and well-being and depressive symptoms in early adolescents. Journal of Child and Family Studies, 27(12), 4044-4059. https://doi.org/10.1007/s10826-018-1215-0

Carroll, J. J., \& Robinson, B. E. (2000). Depression and parentification among adults as related to parental workaholism and alcoholism. The Family Journal, 8(4), 360-367. https://doi.org/10.1177/1066480700084005

Castro, D. M., Jones, R. A., \& Mirsalimi, H. (2004). Parentification and the imposter phenomenon: An empirical investigation. The American Journal of Family Therapy, 32, 205-216.

Celano, M. (2018). Children with emotional and behavioural disorders: Systemsic practise. New York: Momentum.

Chase, N. D. (1999). Burdened children: Theory, research, and treatment of parentification. California: Sage. 
Chase, N. D., Deming, M. P., \& Wells, M. C. (1998). Parentification, parental alcoholism, and academic condition among young adults. American Journal of Family Therapy, 26(2), 105-114. http://dx.doi.org/10.1080/01926189808251091

Cihan-Güngör, H. (2007). Evlilik doyumunu açıklamaya yönelik bir model geliştirme [Developing a model to explain marital satisfaction]. Doctoral Thesis. Gazi University Graduate School of Educational Sciences, Ankara.

Clerici, R., \& Vanin, P. (2002). Validation for Italian context of Jurkovic and Session's Parentification Questionnaire. PIP, Atti della XLI Riunione Scientifica. Padova: CLEUP. Retrieved from http://www.old.sis-statistica.org/files/pdf/atti/RSMi0602p343-346.pdf.

Cuskelly, M., \& Gunn, P. (2003). Sibling relationships of children with Down syndrome: Perspectives of mothers, fathers, and siblings. American Journal of Mental Retardation, 108(4), 234-44. https://doi.org/10.1352/0895-8017(2003)108\%3C234:SROCWD\%3E2.0.CO;2

Çelik, M., \& Yazgan-İnanç, B. (2009). Evlilik doyumu ölçeği: Geçerlik ve güvenirlik çalışmaları. Çukurova Üniversitesi Sosyal Bilimler Enstitüsü Dergisi, 18(2), 247-269. Retrieved from https://dergipark.org.tr/en/pub/cusosbil/issue/4382/60137.

Danby, S., Cromdal, J., Rendle-Short, J., Butler, C. W., Osvaldsson, K., \& Emmison, M. (2015). Parentification: Counselling talk on a helpline for children and young people. In M. O'Reilly, \& J. N. Lester (Eds.), The palgrave handbook of child mental health (pp. 578-596). London: Palgrave Macmillan. https://doi.org/10.1057/9781137428318_31

Davis, M., Blims, J., \& Suveg, C. (2017). In sync and in control: A meta-analysis of parent-child positive behavioural synchrony and youth self-regulation. Family Process, 56(4), 962-980. https://doi.org/10.1111/famp.12259

Derikozis, E. O., \& Wingsiong, A. (2017). Childhood parentification and adulthood depression and anxiety. Paper presented in Canadian Psychological Association 2017 Conference, Toronto. Retrieved from https://www.researchgate.net/publication/317784943_Childhood_Parentification_and _Adulthood_Depression_and_Anxiety.

Earley, L. \& Cushway, D. (2002). The parentified child. Clinical Child Psycholog and Psychiatry, 7(2), 163178. https://doi.org/10.1177\%2F1359104502007002005

Emre, O. (2016). Ebeveynleştirmenin çocukların gelişim sürecine etkisi. İnönü Üniversitesi Sağlık Bilimleri Dergisi, 5(2), 29-34. Retrieved from http://openaccess.inonu.edu.tr:8080/xmlui/bitstream/handle /11616/8289/Makale\%20Dosyas\%c4\%b1.pdf?sequence=1\&isAllowed=y.

Erikson, H. E. \& Erikson, J. (2014). İnsanın 8 evresi (Genişletilmiş Baskı). (G. Akkaya, Trans.). İstanbul: Okuyan Us.

Feldman, S. S., Fisher, L., \& Seitel, L. (1997). The effect of parents' marital satisfaction on young adults' adaptation: A longitudinal study. Journal of Research on Adolescence, 1, 55-80. https://doi.org/10.1207/s15327795jra0701_4

Fitzgerald, M. M. (2005). The impact of parentification on children's psychological adjustment: Emotional management skills as potential underlying process cheese. Doctoral Thesis. University of Georgia Graduate Faculty, Athens. Retrieved from https://getd.libs.uga.edu/pdfs/fitzgerald_monica _m_200508_phd.pdf. 
Fitzgerald, M. M., Schneider, R. A., Salstrom, S., Zinzow, H. M., Jackson, J., \& Fossel, R. V. (2008). Child sexual abuse, early family risk, and childhood parentification: Pathways to current psychosocial adjustment. Journal of Family Psychology, 22(2), 320-324. https://doi.org/10.1037/08933200.22.2.320

Ford, M. C. (2006). The relationships between childhood maltreatment and delinquency. In B. Sims \& P. Preston (Eds.), Handsbook of juvenile justice: Theory and practise (pp.127-143). Taylor \& Francis.

Fraenkel, J. R., Wallen, N. E., \& Hyun, H. H. (2012). How to design and evaluate research in education (8th. ed.). New York: McGraw-Hill Humanities.

Freud, S. (2015). Psikanaliz üzerine beş konferans ve psikanalize toplu bakış. (K. Şipal, Trans.). İstanbul: Say.

George, D. \& Mallery, M. (2010). SPSS for Windows step by step: A simple guide and reference, 17.0 Update (10th ed.). Boston: Pearson.

Godsall, R. E., Jurkovic, G. J., Emshoff, J., Anderson, L., \& Stanwyck, D. (2004). Why some kids do well in bad situations: relation of parental alcohol misuse and parentification to children's selfconcept. Substance Use \& Misuse, 39(5), 789-809. https://doi.org/10.1081/ja-120034016

Goglia, L. R., Jurkovic, G. J., Burt, A. M., \& Burge-Callaway, K. G. (1992). Generational boundary distortions by adult children of alcoholics: Child-as-parent and child-as-mate. American Journal of Family Therapy, 20(4), 291-299. https://doi.org/10.1080/01926189208250899

Gültekin, Z. (2010). Bağlanma ve aile işlevleri açısından anne-baba-çocuk ilişkileri. In T. Solmuş (Ed.), Bağlanma, evlilik ve aile psikolojisi (pp.123-141). İstanbul: Sistem.

Haskan-Avcı, Ö., Zencir, T., Koç, M., \& Tunç, E. (2018). Üniversite öğrencilerinin ebeveynleşme düzeylerinin çeşitli demografik değişkenler açısından incelenmesi. In C. Şahin (Ed.), 20. Uluslararası psikolojik danışma ve rehberlik kongresi tam metin kitabı (pp.141-147). Ankara: Türk Psikolojik Danışma ve Rehberlik Derneği.

Hetherington, E. M. (1999). Should we stay together for the sake of the children? In E. M. Hetherington (Ed.), Coping with divorce, single parenting, and remarriage: A risk and resiliency perspective (pp. 93116). New York: Lawrence Erlbaum Associates.

Heubeck, B. G., Tausch, B., \& Mayer, B. (1995). Models of responsibility and depression in unemployed young males and females. Journal of Community and Applied Social Psychology, 5(5), 291-305. https://doi.org/10.1002/casp.2450050502

Hisli, N. (1988). Beck depresyon envanterinin geçerliği üzerine bir çalişma. Psikoloji Dergisi, 22, 118-126. Retrieved from https://www.academia.edu/1472683/Beck_Depresyon_Envanterinin_Ge\%C3 \%A7erli\%C4\%9Fi_\%C3\%9Czerine_bir_\%C3\%87al\%C4\%B1\%C5\%9Fma.

Hisli, N. (1989). Beck depresyon envanterinin üniversite öğrencileri için geçerliği, güvenirliği. Psikoloji Dergisi, 23(7), 3-13.

Hooper, L. M. (2007). The application of attachment theory and family systems theory to the phenomena of parentification. The Family Journal, 15, 217-223. https://doi.org/10.1177/1066480707301290

Hooper, L. M. (2008). Defining and understanding parentification: Implications for all counsellors. The Alabama Counselling Association Journal, 34(1), 34-43. 
Hooper, L. M. (2009). Individual and family resilience: definitions, re-search, and frameworks relevant for all counsellors. The Alabama Counseling Association Journal, 35(1), 19-26. Retrieved from https://files.eric.ed.gov/fulltext/EJ875400.pdf.

Hooper, L. M., Doehler, K., Jankowski, P. J., \& Tomek, S. E. (2012). Patterns of self-reported alcohol use, depressive symptoms, and body mass index in a family sample: the buffering effects of parentification. The Family Journal, 20(2), 164-178. https://doi.org/10.1177/1066480711435320

Hooper, L. M., Tomek, S., Bond, J. M., \& Reif, M. S. (2015). Race/ethnicity, gender, parentification, and psychological functioning: Comparisons among a nationwide university sample. The Family Journal, 23(1), 33-48. https://doi.org/10.1177/1066480714547187

Hooper, L. M., \& Wallace, S. A. (2009). Evaluating the parentification questionnaire: Psychometric properties and psychopathology correlates. Contemporary Family Therapy: An International Journal, 32, 52-68. https://doi.org/10.1007/s10591-009-9103-9

İşmen-Gazioğlu, A. E. (2011). Aile yaşam döngüsü. In H. Yavuzer (Ed.), Evlilik okulu (7th ed.) (pp. 29-47). İstanbul: Remzi.

Jones, R. A., \& Wells, M. (1996). An empirical study of parentification and personality. The American Journal of Family Therapy, 24(2), 145-152. https://doi.org/10.1080/01926189608251027

Jurkovic, G. J. (1997). Lost childhood: The plight of the parentified child. Brunner/Mazel.

Jurkovic, G. J., Morrell, R., \& Thirkield, A. (1999). Assessing childhood parentification: Guidelines for researchers and clinicians. In. N. D. Chase (Ed.), Burdened children: Theory, research and treatment of parentification (pp. 92-113.). Thousand Oaks: Sage. https://doi.org/10.4135/9781452220604.n4

Jurkovic, G. J., Thirkield, A., \& Morrell, R. (2001). Parentification of adult children of divorce: A multidimensional analysis. Journal of Youth and Adolescence, 30(2), 245-257.

Kagitcibasi, C., Sunar, D., \& Bekman, S. (2001). Long-term effects of early intervention: Turkish lowincome mothers and children. Journal of Applied Developmental Psychology, 22(4), 333-361. https://doi.org/10.1016/S0193-3973(01)00071-5

Karasar, N. (2000). Bilimsel araştırma yöntemleri: Kavramlar, ilkeler, terimeler (10th. ed.). Ankara: Nobel.

Koç, A. (2016). Struggle at the threshold: The mother-in-law and father-in-law wrestling in Anatolian weddings. The Journal of International Social Research 9(42), 252-274. https://doi.org/10.17719/jisr.20164216144

Köyden, D. (2015). The relationship between parentification and depression, anxiety, anger and obsessive beliefs. Master's Thesis. Hacettepe University Graduate School of Social Sciences, Ankara.

Lamorey, S. (1999). Parentification of siblings of children with disability and chronic disease. In. N. D. Chase (Ed.), Burdened children: Theory, research and treatment of parentification (pp. 75-91.). Thousand Oaks: Sage. https://doi.org/10.4135/9781452220604.n4

Leon, K., \& Rudy, D. (2005). Family processes and children's representations of parentification. Journal of Emotional Abuse, 5(2-3), 111-142.

Lewandowska-Walter, A., Borchet, J., Rostowska, T., Polomski, P., \& Peplinska, A. (2017). Parentification and coping in polish adolescents. Polish Journal of Social Science, 12(1), 157-176. Retrieved from https://www.researchgate.net/publication/325386504. 
Lower, L. M. (2005). Couples with young children. In M. Harway (Ed), Handbook of couples therapy (pp. 44-60). New Jersey: John Wiley \& Sons.

Madden, A. R, \& Shaffer, A. (2016). The relation between parentification and dating communication: The role of romantic attachment-related cognitions. The Family Journal, 24(3), 313-318. https://doi.org/10.1177\%2F1066480716648682

McMahon, T. J., \& Luthar, S. S. (2007). Defining characteristics and potential consequences of caretaking burden among children living in urban poverty. American Journal of Orthopsychiatry, 77(2), 267281. https://doi.org/10.1037/0002-9432.77.2.267

Minuchin, S., Montalvo, B., Guerney, B. G., Rosman, B. L., \& Schumer, F. (1967). Families of the slums: An exploration of their structure and treatment. New York: Basic.

Minuchin, S., Rosman, B. L., \& Baker, L. (1978). Psychosomatic families: Anorexia nervosa in context. London: Harvard University.

Nazlı, S. (2014). Aile danışmanliğı (11 th ed.). Ankara: Anı.

Özabaci, N. (2011). Evlilik öncesi ilişkiler. In H. Yavuzer (Ed.), Evlilik okulu (7th ed.) (pp. 48-60). İstanbul: Remzi.

Pasternak, A. \& Schier, K. (2012). The role reversal in the families of adult children of alcoholics. Archives of Psychiatry and Psychotherapy, 3, 511-57. Retrieved from http://w.archivespp.pl/uploads/images/2012_14_3/Pasternak51_ArchivesPP_3_2012.pdf.

Peris, T. S., Goeke-Morey, M. C., Cummings, E. M., \& Emery, R. E. (2008). Marital conflict and support seeking by parents in adolescence: Empirical support for the parentification construct. Journal of Family Psychology, 22(4), 633-642. https://doi.org/10.1037/a0012792

Prime Ministry General Directorate of Family and Social Research. (2010). Aile yapısı araştırması. Ankara: Diner.

van der Mijl, R. C. \& Vingerhoets, A. J. (2017). The positive effects of parentification: An exploratory study among students. Psihologijske teme, 26(2), 417-430. https://doi.org/10.31820/pt.26.2.8

Sfoggia, A., Pacheco, M. A., \& Grassi-Oliveira, R. (2008). History of childhood abuse and neglect and suicidal behavior at hospital admission. Crisis, 29, 154-158. https://doi.org/10.1027/02275910.29.3.154

Shifren, K. (2001). Early caregiving and adult depression: Good news for young caregivers. The Gerontologist, 41(2), 188-190. https://doi.org/10.1093/geront/41.2.188

Sroufe, L. A., Cooper, R. G., \& Dehart, R. D. (1996). Child development (3 ${ }^{\text {rd }}$ ed.). New York: McGraw-Hill.

Stalfa-Jr, F. J. (1994). Vocation as autobiography: Family of origin influences on the caregiving role in ministry. Journal of Pastoral Care, 48(4), 370-380. https://doi.org/10.1177/002234099404800407

Stein, J. A., Riedel, M., \& Rotheram-Borus, M. J. (1999). Parentification and its impact on adolescent children of parents with AIDS. Family Process, 38, 193-208. https://doi.org/10.1111/j.15455300.1999.00193.x

Stein, J. A., Rotheram-Borus, M. J., \& Lester, P. (2007). Impact of parentification on long-term outcomes among children of parents with HIV / AIDS. Family Process, 46(3), 317-333. https://doi.org/10.1111/J.1545-5300.2007.00214.X 
Szymańska, P. (2021). The role of siblings in the process of forming life satisfaction among young adultsmoderating function of gender. Current Psychology, 40, 61323-6144. https://doi.org/10.1007/s12144-020-00776-3

Valleau, M.D., Bergner, R. M., \& Horton, C. B. (1995). Parentification and caretaker syndrome: An empirical investigation. Family Therapy, 22, 157-164.

Wells, M. \& Jones, R. A. (1999). Object relations therapy for individuals with narcissistic and masochistic parentification styles. In N. D. Chase (Ed.), Burdened children: Theory, research and treatment of parentification (pp. 117-131). Thousand Oaks: Sage. https://doi.org/10.4135/9781452220604.n6

Wingsiong, A. C. (2015). Parentification, coping, and distress in siblings of individuals with and without attention-deficit/hyperactivity disorder (ADHD). Master's Thesis. University of Windsor the Faculty of Graduate Studies, Ontario.

Ylldırım, F. (2016). Examining the effects of family unpredictability and parentification on university students' depression level, anger styles and obsessive beliefs. Master's Thesis. Hacettepe University the Graduate School of Social Sciences, Ankara.

Zencir, T \& Haskan-Avc1, Ö. (2019). Development of the parentified child scale- adult version: A reliability and validity study. Çukurova University Faculty of Education Journal, 48(1), 531-553. Retrieved from https://dergipark.org.tr/en/pub/cuefd/issue/44511/443707.

\section{Author Contribution Statement}

The author confirms sole responsibility for the following: study conception and design, data collection, analysis and interpretation of results, and manuscript preparation.

\section{Acknowledgements}

I would like to thank Dr. Özlem Haskan Avcl, whose support I always feel during the thesis writing process. In addition, no support was received from any institution or organization during the execution of the study.

\section{Conflict of Interest}

There is no conflict of interest.

\section{Ethical Statement}

This study was carried out in accordance with the approval of Hacettepe University Ethics Committee dated July 17, 2018 and numbered 35853172-300. 